\title{
MRI diagnosis of megarectum in pregnant women
}

\author{
Sami Kouki, Wissem Ben Mansoura ${ }^{2}$
}

${ }^{1}$ Radiology, Medicine School of Tunis Tunisia, tunis, tunis, Tunisia ${ }^{2}$ Department of Radiology, Hopital Militaire Principal d'Instruction de Tunis, Tunis, Tunisia

Correspondence to Dr Sami Kouki, koukisemi@yahoo.fr

SK and WBM contributed equally.

Accepted 16 February 2018

\section{DESCRIPTION}

A 33-year-old pregnant woman presented at 9 weeks' gestation for a voluntary abortion after an unwanted pregnancy. She had a history of long-standing abdominal distension and childhood constipation, and also a non-complicated pregnancy with normal vaginal delivery few years ago. The clinical examination revealed a distended abdomen. Ultrasound showed a great non-characterisable pelvic abdominal mass repressing pelvic organs, pushing forward and to the right the bladder and to the left the uterus. It also shows an early viable intrauterine pregnancy and no other intra-abdominal abnormalities (figure 1). MRI with multiplanary acquisitions shows that the pelvic mass seen on ultrasound examination has been a large rectum containing a giant fecaloma revealing a megarectum (figure 2). Therapeutic discontinuation of pregnancy was realised then the patient was operated. She had a mucosal proctectomy associated to a sigmoidectomy with colorectal anastomosis. ${ }^{1}$ The operative sequences were simple. This entity can be revealed late by a pelvic symptomatology. ${ }^{2}$ The presence of the fetus presents a challenge in both the diagnosis and treatment of these syndromes. ${ }^{3}$

\section{Learning points}

- Megarectum is a very rare entity.

- Its diagnosis is often late.

- MRI is very specific for the diagnosis of megarectum in front of a pelvic mass.

\section{Contributors SK: manuscript. WBM: bibliography.}

Funding This research received no specific grant from any funding agency in the public, commercial or not-for-profit sectors.

Competing interests None declared.

Patient consent Obtained.

Provenance and peer review Not commissioned; externally peer reviewed.

(c) BMJ Publishing Group Ltd (unless otherwise stated in the text of the article) 2018. All rights reserved. No commercial use is permitted unless otherwise expressly granted.

\section{REFERENCES}

1 Glasser JG, Nottingham JM, Durkin M, et al. Case series with literature review: surgical approach to megarectum and/or megasigmoid in children with unremitting constipation. Ann Med Surg 2018;26:24-9.

2 Kouki S, Fares A, Akkari K, et al. Unusual cause of pelvis pain and polyuria in an adolescent: idiopathic megarectum. JBR-BTR 2013;96:264.

3 Grossmann EM, Kaminski DL, Amon E, et al. Idiopathic megarectum complicating pregnancy: report of a case. Am J Gastroenterol 2000;95:2969-72.

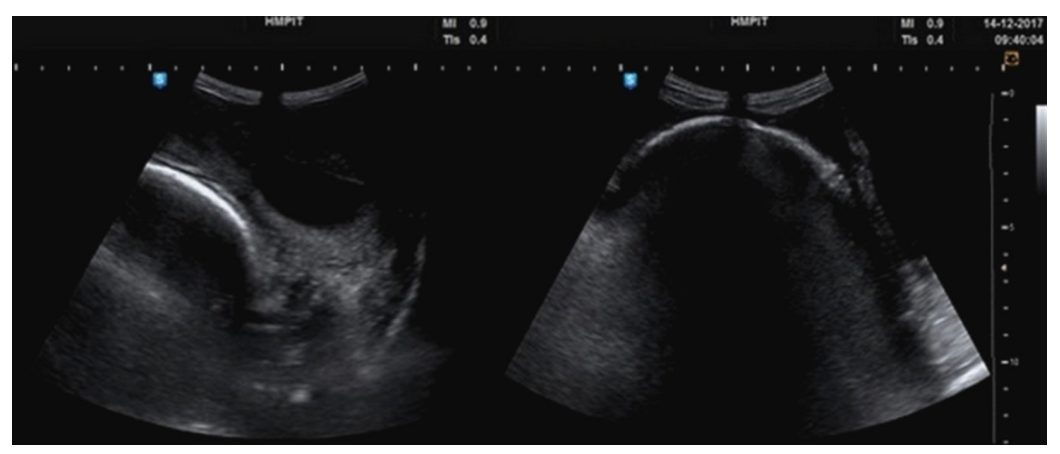

Figure 1 Pelvic ultrasound shows a posterior great non-specific mass pushing the pelvic organs forward.

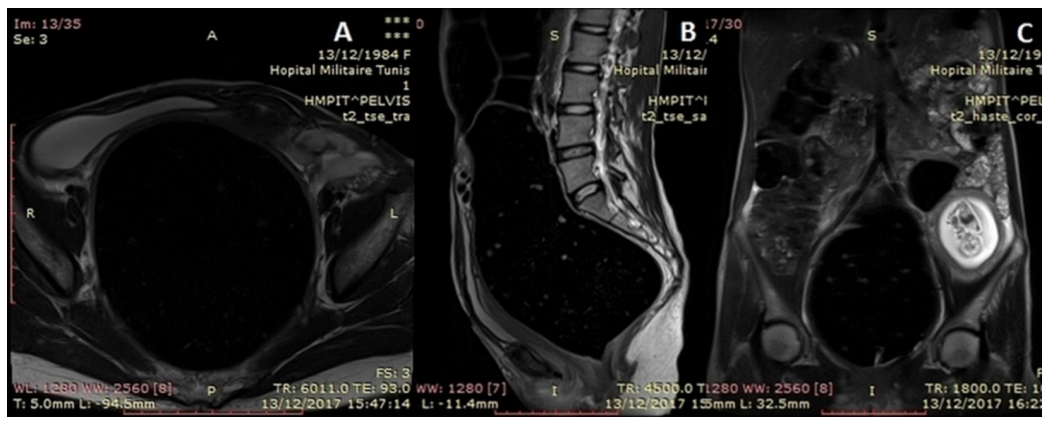

To cite: Kouki S,

Ben Mansoura W. BMJ Case Rep Published Online First: [please include Day Month Year]. doi:10.1136/bcr-2018224418

\section{Check for updates}

Figure 2 Abdominal MRI-transversal (A), sagittal (B) and coronal (C) T2-weighted slices—showing the rectum to the rectosigmoid junction massively distended, measuring $14 \mathrm{~cm}$ in axial diameter, and is occupied by a large fecaloma. 
Copyright 2018 BMJ Publishing Group. All rights reserved. For permission to reuse any of this content visit http://group.bmj.com/group/rights-licensing/permissions.

BMJ Case Report Fellows may re-use this article for personal use and teaching without any further permission.

Become a Fellow of BMJ Case Reports today and you can:

- Submit as many cases as you like

- Enjoy fast sympathetic peer review and rapid publication of accepted articles

Access all the published articles

- Re-use any of the published material for personal use and teaching without further permission

For information on Institutional Fellowships contact consortiasales@bmjgroup.com

Visit casereports.bmj.com for more articles like this and to become a Fellow 